\title{
Vitamin D levels of 12-24-month-old healthy children in Turkey who received vitamin D supplementation until the age of one year
}

\author{
Gizem Kara Elitok, M.D ${ }^{a}$, Lida Bulbul, M.D $D^{b}$, Ali Bulbul, Professor ${ }^{a}$, \\ Sebnem Cigerli, M.D ${ }^{c}$ and Sinan Uslu, Assistant Professor. ${ }^{a}$
}

\begin{abstract}
Introduction. The aim of this study was to evaluate vitamin $D$ levels between 12 -24 monthold healthy children supplemented with vitamin D (400 IU/ day) during the first year.

Methods. Descriptive-sectional study conducted between June 2015, and May 2016, in Istanbul (latitude $41^{\circ} \mathrm{N}$ ). Children aged $12-24$ months followed up by the well-child clinic who had vitamin D supplementation in the first year were included in the study. The levels of calcium, phosphorus, alkaline phosphatase, parathyroid hormone and 25-hydroxyvitamin D [25(OH)D] were measured. Vitamin D status was defined as $>20 \mathrm{ng} / \mathrm{mL}$ : sufficiency, $15-20 \mathrm{ng} / \mathrm{mL}$ : insufficiency and $<15 \mathrm{ng} / \mathrm{mL}$ : deficiency.

Results. The study was completed with 197 children. $26.9 \%$ of children $(n=53)$ went on receiving supplementation after one year (mean dose $491 \pm 267 \mathrm{IU} /$ day). The mean $25(\mathrm{OH}) \mathrm{D}$ level was $38.0 \pm 13.9 \mathrm{ng} / \mathrm{mL}$. It was found that regular vitamin $\mathrm{D}$ intake under one year of age $(\mathrm{p}=0.008)$ and continued support after one year of age ( $p=0.042)$ increased level of 25(OH)D in children aged 12-24 months. VitaminD deficiency was found in $4.1 \%$ and vitamin D insufficiency in $7.1 \%$. Mother's education $(p=0.009)$ and use of formula $(p=0.012)$ were protective factors in relation to development of vitamin D deficiency or insufficiency.

Conclusions. The level of 25(OH)D was sufficient in $88.8 \%$ of children aged $12-24$ months receiving $400 \mathrm{IU} /$ day vitamin D supplementation in the first year. Vitamin D supplementation could not be required in healthy children aged 1224 months who received properly vitamin D supplementation in the first year.

Keywords: vitamin D, children, dietary supplements, infant.
\end{abstract}

http:/ / dx.doi.org/ 10.5546/ aap.2020.eng.95

Gizem Kara Elitok, M.D.: drgizemkara@gmail.com

Funding:

This research was supported by Şiş̧li Hamidiye Etfal

Education and Research Hospital of Education

Planning Board.

Conflict of interest:

None.

Received: 3-20-2019

Accepted: 9-4-2019

\section{INTRODUCTION}

What should be the ideal dose of vitamin D supplementation in children? For how long should we give vitamin $\mathrm{D}$ supplementation to children? Do the geographic latitudes of countries affect the dose and duration of vitamin D supplementation? Currently, there is no consensus on standardized and accepted vitamin D supplementation for children. Vitamin D deficiency continues to be an important public health problem throughout the world. ${ }^{1-3}$ In addition to the effect of vitamin D on calcium-phosphorus metabolism and bone health, the relationship between cardiovascular diseases, diabetes mellitus, cancer, autoimmune diseases, and infectious diseases has been more clearly identified in recent years. ${ }^{1,3,4}$

The lack of exposure to sunlight or insufficient amounts of vitamin D taken with nutrients constitutes two important causes of vitamin D deficiency. ${ }^{2,5}$ In many countries, scientific societies recommendations and support programs for the prevention of vitamin D deficiency are being implemented. ${ }^{6}$ In the first year of life, 400 international units (IU) daily vitamin D supplements are recommended in the treatment guidelines. ${ }^{7,8}$ The Lawson Wilkins Pediatric Endocrine Society also recommends $400 \mathrm{IU}$ per day for all breastfed infants from within days of birth until they ingest at least 1 liter of vitamin D-fortified milk., ${ }^{5,9}$ The European Food Safety Authority (EFSA) recommends $400 \mathrm{IU}$ vitamin D per day for infants to keep serum 25-hydroxyvitamin D [25(OH)D] level above $20 \mathrm{ng} / \mathrm{mL}(50 \mathrm{nmol} / \mathrm{L})$, and 
600 IU vitamin D per day for older children. ${ }^{10}$ The recommended doses over the age of one year vary considerably from country to country. The Institute of Medicine recommends 600 IU vitamin D per day, the DACH guidelines (for German-speaking countries: Germany, Austria and Switzerland) recommend 800 IU per day, and the French guidelines recommend 1000-1200 IU per day for children aged 1-3 years. ${ }^{8}$

In our country, to prevent vitamin D deficiency, a national program has been applied since 2005. With this program, a free-of-charge 400 IU daily vitamin D supplementation is offered to all children until the age of one year by the Ministry of Health. ${ }^{11}$ However, vitamin D supplementation is recommended in all treatment guidelines for children over the age of one year if dietary intake is inadequate and exposure to sunlight is low. ${ }^{8,10}$ There is no consensus about how long vitamin D supplementation should be given after the age of one year.

In this study, we aimed to evaluate vitamin D levels between 12-24 month-old healthy children supplemented with vitamin D (400 IU/day) during the first year. The second aim was to determine the need for vitamin D supplementation in healthy children aged 1224 mouths who received properly vitamin D supplementation in the first year.

\section{POPULATION AND METHODS}

Our descriptive-sectional study was conducted between June $1^{\text {st }}, 2015$, and May $31^{\text {st }}, 2016$, in Istanbul. The geographic latitude of Istanbul is 41 degrees and it is one of the sunniest cities in Turkey. The study was approved by the Et2hics Committee of the Sisli Hamidiye Etfal Education and Research Hospital (897/2015). Oral and written consents were obtained from families who agreed to participate in the study.

\section{Study Group}

Children aged 12-24 months and followed up by the well-child clinic of the Sisli Hamidiye Etfal Education and Research Hospital who had vitamin D supplementation for at least six months in the first year of their lives were included in the study consecutively.

Determination of sample size: The number of children within the specified range of age followed up by the well-child clinic in the last year was 648. The statistical analysis was done. Predicting that this number of children would be admitted in the study year, the sample size was calculated to be 192 with a $5 \%$ error rate and $90 \%$ confidence interval to reflect the 1-year cohort.

\section{Exclusion criteria}

Children with chronic disorders, malabsorption, growth and development retardation (weight and/or height $<3$ rd percentile), genetic syndromes, metabolic disease, children who used drugs that could affect vitamin D metabolism (anticonvulsants), preterm born before 37 weeks of gestation, children who never received vitamin D supplementation under the age of one year, and children who received vitamin $\mathrm{D}$ supplementation less than 3 days a week or less than 6 months were excluded from the study.

\section{Study procedures}

The sociodemographic data of the children were obtained from the follow-up cards and the study data form, which was completed through face-to-face interviews with the mothers of the children. The data included the sociodemographic characteristics and nutrition habits (duration of feeding with breast milk -timing of the complementary feeding- amount of formulacow's milk intake).

Children receiving vitamin D supplementation five or more days a week were recorded as "regular use," and those who received supplementation 3 or 4 days a week were recorded as "irregular use." Anthropometric measurements (weight, height, head circumference) of the children were taken.

Venous blood samples taken between November to April were defined as "winter season" and May to October as "summer season." The collected samples were delivered to the laboratory and protected from light, and serum samples were separated using a cooling centrifuge for 10 minutes at $2000 \mathrm{rpm}$. Parathyroid hormone (PTH) and 25-hydroxyvitamin D [25(OH)D] levels were measured using an electrochemiluminescence immunoassay (ECLIA; Roche Cobas 8000 immunoassay). Serum calcium and phosphorus levels were measured using photometry and alkaline phosphatase (ALP) levels were measured using standardized colorimetry (ECLIA; Roche Cobas 8000 immunoassay).

Vitamin D status was classified according to the Drug and Therapeutics Committee of the Lawson Wilkins Pediatric Endocrine Society (LWEPS) recommendation about cut-off levels 
for vitamin D status $[25(\mathrm{OH}) \mathrm{D}<15 \mathrm{ng} / \mathrm{mL}$ : deficiency, 15-20 ng/mL: insufficiency, >20-100 $\mathrm{ng} / \mathrm{mL}$ : sufficiency]. ${ }^{5}$

\section{Statistical methods}

Statistical analysis was performed using SPSS 15.0 for Windows. Descriptive statistics were given as mean and standard deviation for numeric variables, and number and percentages for categorical variables. Student's t-test, one-way ANOVA and Chi-square analysis were used for comparing group's data. Parameters determining numeric variables were analyzed using linear regression analysis. $\mathrm{P}<0.05$ was considered statistically significant.

\section{RESULTS}

Our study was completed with a total of 197 healthy children (99 winter and 98 summer season) (Figure 1). The distribution of sociodemographic data of the study group is presented in Table 1. The average exclusive breastfeeding time was $4.2 \pm 2.6$ months, and the average time to continue feeding with breast milk was $12.9 \pm 6.7$ months. The rate of formula consumption in nutrition was $54.8 \%(\mathrm{n}=108)$ and the average time to continue feeding with formula was $12.5 \pm 4.7$ (range, 2-24) months. The rate of children who still used formula in their diet was $23.9 \%(\mathrm{n}=47)$.

Figure 1. Flow chart of the study

Children excluded (numbers and reasons): $\mathrm{n}: 3$, never received vitamin D supplementation under the age of one year. $\mathrm{n}: 14$, received vitamin D supplementation less than 3 days a week.

n: 5 , received vitamin D supplementation less than 6 months.
643 children aged 12-24 months were followed in well-child clinic in this year.

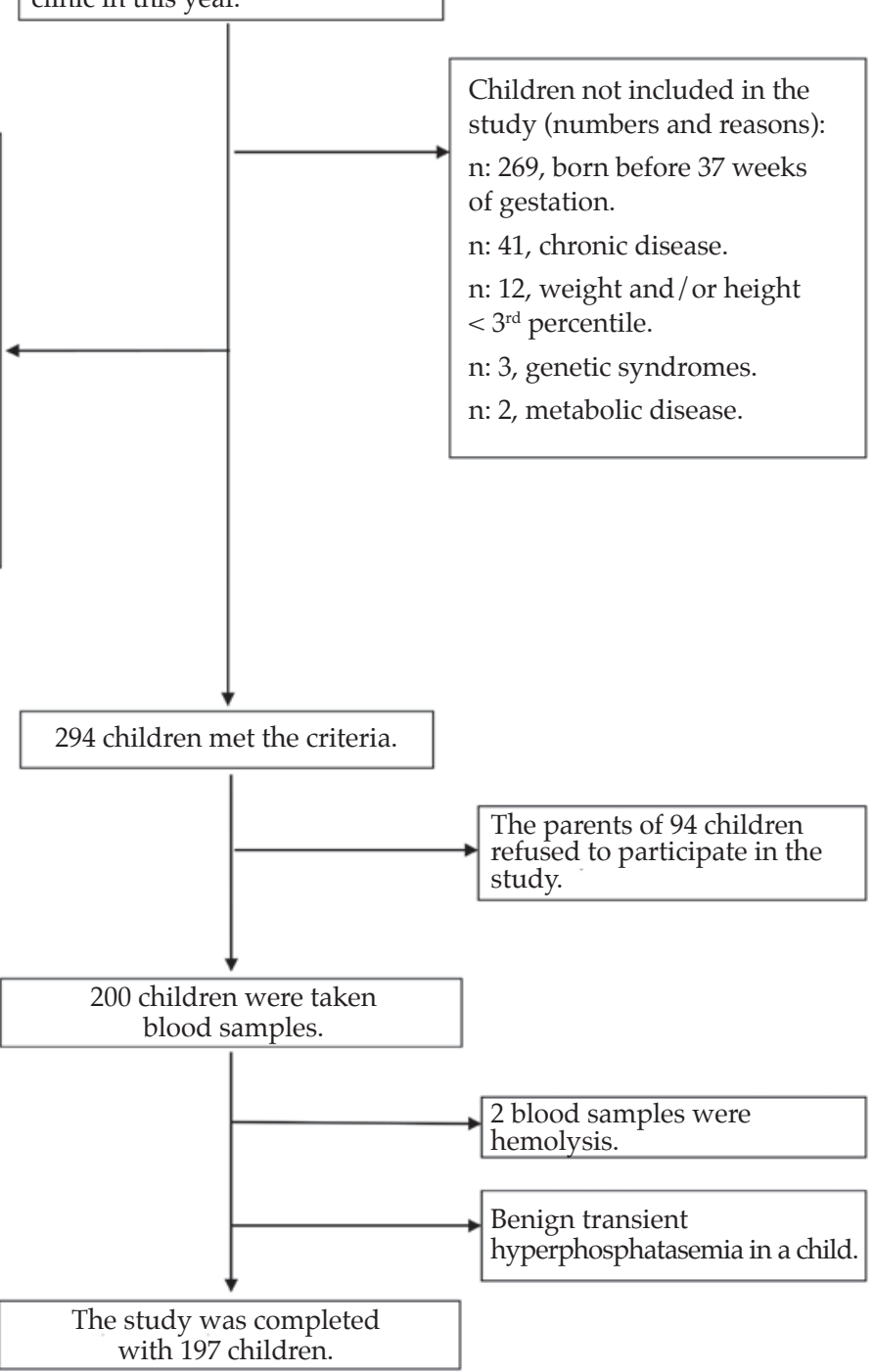


The mean time to start vitamin D was $20.4 \pm 17.2$ (range, 1-120) days. Vitamin D supplementation continued for an average of $12.0 \pm 2.6$ (range, 7-24) months. 53 (26.9\%) children continued to receive vitamin D supplementation after 12 months and the mean time to use vitamin D after 12 months was $3.7 \pm 2.6$ months. The dose of vitamin $\mathrm{D}$ taken after the age of one year was $491 \pm 267 \mathrm{IU} /$ per day. The mean serum 25(OH)D level was $38.0 \pm 13.9 \mathrm{ng} / \mathrm{mL}$ in the study group.

During the first year of life, the frequency of received regular vitamin D supplementation was found $82.7 \%$ ( $\mathrm{n}: 163$ ) and the frequency of irregular vitamin D supplementation use was found $17.3 \%$ (n:34). In our study, we found that vitamin $\mathrm{D}$ levels were statistically correlated with regular use of vitamin D under the age of one year. Vitamin D levels were higher in children aged 12-24 months who received regular vitamin $\mathrm{D}$ supplementation under the age of one year $(\mathrm{p}=0.008)$ (Table 1$)$.

25(OH)D levels were significantly higher $(p=0.042)$ in children aged over one year who continued to use vitamin D supplementation, but it was found that there was no effect on biochemical parameters (Table 2).

Vitamin D levels of children were found sufficient in $88.8 \%(\mathrm{n}=175), 4.1 \%(\mathrm{n}=8)$ had deficiency, and $7.1 \%(\mathrm{n}=14)$ had insufficiency
(Table 3). When factors causing vitamin D deficiency or insufficiency were examined, a statistically significant correlation was found between the level of 25(OH)D in children and the mother's education status $(p=0.009)$ and the child's use of formula $(p=0.012)$. Mothers of the children with vitamin $\mathrm{D}$ deficiency had lower educational status. Vitamin D deficiency and insufficiency were found to be less in children feeding formula. However, there was no statistical relationship between gender, season, monthly income and use of cow's milk and vitamin D levels $(\mathrm{p}=0.066, \mathrm{p}=0.271, \mathrm{p}=0.058, \mathrm{p}=0.454$, respectively) (Table 3 ). When vitamin $\mathrm{D}$ deficiency or insufficiency in children were examined, it was found that 5 of 8 children with deficiency and 12 of 14 children with insufficiency had no supplementation vitamin $\mathrm{D}$ after the age of one year. This relationship was not statistically significant but was remarkable.

When the effect of the season on vitamin $\mathrm{D}$ was evaluated, the average level of $25(\mathrm{OH}) \mathrm{D}$ was $37.8 \pm 13.5 \mathrm{ng} / \mathrm{mL}$ in winter and $38.2 \pm 14.3 \mathrm{ng} /$ $\mathrm{mL}$ in summer $(\mathrm{p}=0.856)$. The distribution of vitamin D deficiency and insufficiency were different between seasons. Sufficient, insufficient and deficient levels were found in $91.8 \%, 4.1 \%$ and $4.1 \%$ during summer, and $85.9 \%, 10.1 \%$ and $4.0 \%$ during winter respectively.

TABLE 1. The distribution of sociodemographic data and the relationship between biochemical parameters and vitamin $D$ levels in children received vitamin D supplementation under the age of one year

\begin{tabular}{|c|c|c|c|}
\hline \multicolumn{2}{|l|}{ Data } & \multicolumn{2}{|l|}{$\begin{array}{c}\text { Mean } \pm \text { Standard Deviation (SD) } \\
\text { (Lower -Upper Limit) }\end{array}$} \\
\hline Gestation (weeks) & & \multicolumn{2}{|l|}{$39.0 \pm 1.1(37-42)$} \\
\hline Birth weight $(\mathrm{g})$ & & \multicolumn{2}{|l|}{$3312 \pm 438(2300-4800)$} \\
\hline Gender, n (\%) & $\begin{array}{l}\text { Male } \\
\text { Female }\end{array}$ & \multicolumn{2}{|l|}{$\begin{array}{c}110(55.8) \\
87(44.2)\end{array}$} \\
\hline \multicolumn{2}{|c|}{ Age at admission to study (months) } & \multicolumn{2}{|l|}{$17.6 \pm 4.5(12-24)$} \\
\hline \multicolumn{2}{|l|}{ Height (cm) } & \multicolumn{2}{|l|}{$82.2 \pm 5.7(70-98)$} \\
\hline \multirow[t]{2}{*}{ 25(OH)D level (ng/mL) } & & \multicolumn{2}{|l|}{$38.0 \pm 13.9(7-114.4)$} \\
\hline & $\begin{array}{l}\text { Regular vitamin } D \text { receivers } \\
\text { under the age of one year } \\
\mathbf{n}=163 \\
\text { Mean } \pm \text { Standard Deviation }\end{array}$ & $\begin{array}{l}\text { Irregular vitamin } D \text { receivers } \\
\text { under the age of one year } \\
\qquad \mathbf{n}=34 \\
\text { Mean } \pm \text { Standard Deviation }\end{array}$ & $\mathbf{P}$ \\
\hline Calcium (mg/dL) & $10.2 \pm 0.4$ & $10.2 \pm 0.4$ & 0.525 \\
\hline Phosphorus (mg/dL) & $5.3 \pm 0.5$ & $5.4 \pm 0.6$ & 0.458 \\
\hline $\operatorname{ALP}(\mathrm{U} / \mathrm{L})$ & $228.3 \pm 81.9$ & $219.2 \pm 65.8$ & 0.416 \\
\hline PTH (ng/L) & $23.4 \pm 10.6$ & $21.3 \pm 12.6$ & 0.089 \\
\hline 25(OH)D level (ng/mL) & $39.0 \pm 14.5$ & $33.5 \pm 9.7$ & 0.008 \\
\hline
\end{tabular}




\section{DISCUSSION}

Serum $25(\mathrm{OH}) \mathrm{D}$ is the major circulating form of vitamin $\mathrm{D}$, and it is considered as a parameter that provides the best information about total body vitamin D status. ${ }^{1,2,5,9}$ The mean serum $25(\mathrm{OH}) \mathrm{D}$ level was found to be higher in children aged 12-24 months in our study compared with the levels reported in the literature. The mean $25(\mathrm{OH}) \mathrm{D}$ level was $28.04 \mathrm{ng} / \mathrm{mL}(70 \mathrm{nmol} / \mathrm{L})$ in the United States in children aged 1-5 years, and $28.65 \mathrm{ng} / \mathrm{mL}(71.5 \mathrm{nmol} / \mathrm{L})$ in China (latitude $31.57^{\circ} \mathrm{N}$ ) in children aged $1-3$ years..$^{12,13}$ The mean 25(OH)D level was $20.95 \mathrm{ng} / \mathrm{mL}(52.3 \mathrm{nmol} / \mathrm{L})$ in Norway (latitude $55^{\circ} \mathrm{N}$ ) in healthy migrant children aged between 9-16 months. ${ }^{14}$ We believe that the free vitamin D supplementation program applied by the Ministry of Health in our country makes a great contribution to the finding of higher the mean 25(OH)D level in our study compared with those of other studies in the literature. In our study, it was found that regular use of vitamin D supplementation under one year of age increased the mean vitamin $D$ level in healthy children aged 12-24 months. Similarly, in a study in 4-month-old infants taking $400 \mathrm{IU}$ vitamin $\mathrm{D}$ daily, the regular use of vitamin $\mathrm{D}$ supplementation was shown to increase the mean 25(OH)D level. ${ }^{15}$ In the same study, vitamin D deficiency was accepted as $20 \mathrm{ng} / \mathrm{mL}$ and regular use of vitamin D supplementation was

TABLE 2. The relationship between biochemical parameters and vitamin D levels in children continued vitamin $D$ supplementation aged over one year

\begin{tabular}{lccc}
\hline & $\begin{array}{c}\text { Continuing vitamin } \mathbf{D} \\
\text { supplementation aged } \\
\text { over one year } \mathbf{n}=\mathbf{5 3}\end{array}$ & $\begin{array}{c}\text { Not continuing vitamin D } \\
\text { supplementation aged } \\
\text { over one year } \mathbf{n}=\mathbf{1 4 4}\end{array}$ & $\mathbf{p}$ \\
\hline & Mean \pm Standard Deviation & & 0.458 \\
\hline Calcium $(\mathrm{mg} / \mathrm{dL})$ & $10.3 \pm 0.5$ & $10.2 \pm 0.4$ & 0.825 \\
Phosphorus (mg/dL) & $5.3 \pm 0.5$ & $5.3 \pm 0.6$ & 0.143 \\
ALP (U/L) & $246.3 \pm 123.3$ & $219.5 \pm 53.7$ & 0.396 \\
PTH (ng/L) & $24.7 \pm 12.8$ & $22.4 \pm 10.1$ & 0.042 \\
25(OH)D level $(\mathrm{ng} / \mathrm{mL})$ & $41.9 \pm 17.4$ & $36.6 \pm 12.1$ & \\
\hline
\end{tabular}

Table 3. Factors affecting the development of vitamin D deficiency and insufficiency

\begin{tabular}{|c|c|c|c|c|c|}
\hline & & \multicolumn{3}{|c|}{ 25(OH)D level } & \\
\hline & & $\begin{array}{l}\text { Deficiency } \\
<15 \text { (ng/mL) }\end{array}$ & $\begin{array}{l}\text { Insufficiency } \\
15-20(\mathrm{ng} / \mathrm{mL})\end{array}$ & $\begin{array}{c}\text { Sufficiency } \\
>20-100(\mathrm{ng} / \mathrm{mL})\end{array}$ & \\
\hline & & n $(\%)$ & n $(\%)$ & n $(\%)$ & $\mathrm{p}$ \\
\hline Group of age & $\begin{array}{l}12-17 \text { months } \\
18-24 \text { months }\end{array}$ & $\begin{array}{l}1(12.5) \\
7(87.5)\end{array}$ & $\begin{array}{l}3(21.4) \\
11(78.6)\end{array}$ & $\begin{array}{l}71(40.6) \\
104(59.4)\end{array}$ & 0.150 \\
\hline Gender & $\begin{array}{l}\text { Male } \\
\text { Female }\end{array}$ & $\begin{array}{l}6(75) \\
2(25)\end{array}$ & $\begin{array}{c}4(28.6) \\
10(71.4)\end{array}$ & $\begin{array}{l}100(57.1) \\
75(42.9)\end{array}$ & 0.066 \\
\hline Season & $\begin{array}{l}\text { Summer } \\
\text { Winter }\end{array}$ & $\begin{array}{l}4(50) \\
4(50)\end{array}$ & $\begin{array}{c}4(28.6) \\
10(71.4)\end{array}$ & $\begin{array}{l}90(51.4) \\
85(48.6)\end{array}$ & 0.271 \\
\hline $\begin{array}{l}\text { Education status } \\
\text { of mother }\end{array}$ & $\begin{array}{l}\text { Illiterate } \\
\text { Primary school } \\
\text { Secondary school } \\
\text { University }\end{array}$ & $\begin{array}{c}3(37.5) \\
4(50) \\
1(12.5) \\
0(0)\end{array}$ & $\begin{array}{l}3(21.4) \\
4(28.6) \\
3(21.4) \\
4(28.6)\end{array}$ & $\begin{array}{c}8(4.6) \\
78(44.6) \\
45(25.7) \\
44(25.1)\end{array}$ & 0.009 \\
\hline $\begin{array}{l}\text { Monthly income } \\
\text { of family }\end{array}$ & $\begin{array}{l}<600 \$ \\
600-900 \$ \\
>900 \$\end{array}$ & $\begin{array}{c}8(100) \\
0 \\
0\end{array}$ & $\begin{array}{c}10(71.4) \\
3(21.4) \\
1(7.1)\end{array}$ & $\begin{array}{l}88(50.3) \\
50(28.6) \\
37(21.1)\end{array}$ & 0.058 \\
\hline Feeding with formula & $\begin{array}{l}\text { Yes } \\
\text { No }\end{array}$ & $\begin{array}{l}1(12.5) \\
7(87.5)\end{array}$ & $\begin{array}{l}5(35.7) \\
9(64.3)\end{array}$ & $\begin{array}{l}102(58.3) \\
73(41.7)\end{array}$ & 0.012 \\
\hline Cow's milk & $\begin{array}{l}\text { Yes } \\
\text { No }\end{array}$ & $\begin{array}{l}3(37.5) \\
5(32.5)\end{array}$ & $\begin{array}{l}9(64.3) \\
5(35.7)\end{array}$ & $\begin{array}{l}85(48.6) \\
90(51.4)\end{array}$ & 0.454 \\
\hline $\begin{array}{l}\text { Vitamin D } \\
\text { supplementation } \\
\text { after the age one year }\end{array}$ & $\begin{array}{l}\text { Yes } \\
\text { No }\end{array}$ & $\begin{array}{l}3(37.5) \\
5(62.5)\end{array}$ & $\begin{array}{c}2(14.3) \\
12(85.7)\end{array}$ & $\begin{array}{c}48(27.4) \\
127(72.6)\end{array}$ & 0.448 \\
\hline
\end{tabular}


shown to decrease the development of vitamin $\mathrm{D}$ deficiency. ${ }^{15}$ In our study, continuing vitamin D supplementation after the age of one year was found to increase 25(OH)D levels in children. The effect of continuing vitamin D supplementation after the age of one year, on the development of vitamin $\mathrm{D}$ deficiency or insufficiency, could not be evaluated due to the low number of patients in the vitamin D deficiency and insufficiency groups.

The cut-off value of $25(\mathrm{OH}) \mathrm{D}$ level defining optimal vitamin D status varies according to different authors and guidelines. The American Academy of Pediatrics (AAP), Institute of Medicine (IOM), and the European Society of Paediatric Gastroenterology, Hepatology and Nutrition (ESPGHAN) suggest that the cut-off value of serum 25(OH)D level should be $20 \mathrm{ng} /$ $\mathrm{mL} .2,3,5,7,10$ According to the AAP and the IOM, serum $25(\mathrm{OH}) \mathrm{D}$ level $\leq 15 \mathrm{ng} / \mathrm{mL}$ is defined as "vitamin D deficiency" and serum 25(OH)D level between 15-20 ng/mL is defined as "vitamin D insufficiency". ${ }^{2,5}$ In our study, according to AAP and IOM cut-off values, in the majority $(88.8 \%)$ of children under the age of one year receiving $400 \mathrm{IU} /$ day vitamin D supplementation, 25(OH D levels were sufficient. The rates of vitamin D deficiency $(4.1 \%)$ and insufficiency $(7.1 \%)$ were low in our study. In another study, similar to our results, it was found that the frequencies of vitamin D deficiency and insufficiency in infants aged 3-18 months were $4.7 \%$ and $7.1 \%$, respectively. ${ }^{16}$ However, in a study conducted in our region in healthy children $400 \mathrm{IU} /$ day vitamin D supplementation dose in the first year was insufficient; $25(\mathrm{OH}) \mathrm{D}$ levels in $30 \%$ of the children aged 12-24 months were reported to be below $15 \mathrm{ng} / \mathrm{mL} .{ }^{17}$ The results of that study were quite different from our results, possibly due to the fact that the children included in that study were only fed with breast milk and did not receive formula. Similarly, in a study in 4-monthold infants fed breast milk only and receiving 400 $\mathrm{IU} /$ day vitamin D supplementation, 25(OH D levels were reported to be below $20 \mathrm{ng} / \mathrm{mL}$ in $28 \%$ of the children. ${ }^{15}$

Nutritional models of infants affect serum $25(\mathrm{OH}) \mathrm{D}$ levels. In a study in 9-month-old infants in Denmark, $89 \%$ of the infants receiving $10 \mu \mathrm{g} /$ day (400 IU / day) vitamin D supplementation had sufficient vitamin D level, but vitamin D levels were lower in infants with only breastfeeding. ${ }^{18}$ In our study, there was a significant correlation between the use of formula and 25(OH)D levels.
According to studies conducted in our country, the rate of maternal vitamin D deficiency is $80 \%$ and the risk of development of vitamin D deficiency in children with only breastfeeding is higher. ${ }^{11,19,20}$ In our study, vitamin D deficiency and insufficiency rates in children who used formula in their diet were lower than those who used breast milk alone.

It is known that the level of vitamin D is seasonal variation. In a study conducted in Denmark (latitude $55^{\circ} \mathrm{N}$ ), vitamin D levels were higher in summer and autumn months compared with winter and spring months. ${ }^{18}$ In a study from China, vitamin D deficiency was reported to be higher in autumn. ${ }^{13}$ In a study conducted in our country, vitamin D levels marked seasonal differences, and it was suggested that $400 \mathrm{IU} /$ day vitamin D supplementation should be increased especially in the winter months. ${ }^{15}$ However, a recent study in Norway (latitude $55^{\circ} \mathrm{N}$ ) reported that vitamin $\mathrm{D}$ levels showed no seasonal variation. ${ }^{14}$ In our study no significant seasonal variations were found in vitamin D levels. However, it is remarkable that the vitamin D deficiency rate was twice more in winter compared with summer.

\section{Limitations}

The first limitation is that it was only made in the city of Istanbul. Therefore, it may give limited information about the general population of the country. The second limitation is that the dose and duration of vitamin D supplementation given to children and the information about the children's nutritional status were based on their mother's declaration.

The strengths of our study are that it was made in a healthy population and that blood samples were taken in routine health examinations rather than during the disease. Another strength is that blood samples are taken throughout the year instead of a season.

\section{CONCLUSION}

In this study, we found that the level of $25(\mathrm{OH}) \mathrm{D}$ was sufficient in $88.8 \%$ of children aged 12-24 months who received $400 \mathrm{IU} /$ day vitamin $D$ supplementation in their first year. The rates of vitamin D deficiency and insufficiency were $4.1 \%$ and $7.1 \%$, respectively. Vitamin D supplementation could not be required in healthy children aged 12-24 months who received properly vitamin D supplemented in the first year. 


\section{REFERENCES}

1. Hossein-nezhad A, Holick MF. Vitamin D for Health: A Global Perspective. Mayo Clinic. 2013; 88(7):720-55.

2. Balasubramanian S, Dhanalakshmi K, Amperayani S. Vitamin D deficiency in childhood-a review of current guidelines on diagnosis and management. Indian Pediatr. 2013; 50(7):669-75.

3. Saggese G, Vierucci F, Boot AM, Czech-Kowalska J, et.al. Vitamin Din childhood and adolescence: an expert position statement. Eur J Pediatr. 2015; 174(5):565-76.

4. Pludowski P, Holick MF, Grant WB, Konstantynowicz J, et al. Vitamin D supplementation guidelines. J Steroid Biochem Mol Biol. 2018; 175:125-35.

5. Misra M, Pacaud D, Petryk A, Collett-Solberg PF, et al. Vitamin D deficiency in children and its management: review of current knowledge and recommendations. Pediatrics. 2008; 122(2):398-417.

6. Uday S, Kongjonaj A, Aguiar M, Tulchinsky T, Högler W. Variations in infant and childhood vitamin D supplementation programmes across Europe and factors influencing adherence. Endocr Connect. 2017; 6(8):667-75.

7. Munns CF, Shaw N, Kiely M, Specker BL, et al. Global Consensus Recommendations on Prevention and Management of Nutritional Rickets. JClin Endocrinol Metab. 2016; 101(2):394-415.

8. Bouillon R. Comparative analysis of nutritional guidelines for vitamin D. Nat Rev Endocrinol. 2017; 13(8):466-79.

9. Wagner CL, Greer FR; American Academy of Pediatrics Section on Breastfeeding; American Academy of Pediatrics Committee on Nutrition. Prevention of rickets and vitamin D deficiency in infants, children, and adolescents. Pediatrics. 2008; 122(5):1142-52.

10. Grossman Z, Hadjipanayis A, Stiris T, Del Torso S, et al. Vitamin D in European children-statement from the European Academy of Paediatrics (EAP). Eur J Pediatr. 2017; 176(6):829-31.
11. Hatun S, Ozkan B, Bereket A. Vitamin D deficiency and prevention: Turkish experience. Acta Paediatr. 2011; 100(9):1195-9.

12. Mansbach JM, Ginde AA, Camargo CA Jr. Serum 25-hydroxyvitamin D levels among US children aged 1 to 11 years: do children need more vitamin D? Pediatrics. 2009; 124(5):1404-10.

13. Zhao X, Xiao J, Liao X, Cai L, et al. Vitamin D Status among Young Children Aged 1-3 Years: A Cross-Sectional Study in Wuxi, China. PloS One. 2015; 10(10):e0141595.

14. Madar AA, Gundersen TE, Haug AM, Meyer HE. Vitamin D supplementation and vitamin D status in children of immigrant background in Norway. Public Health Nutr. 2017; 20(16):2887-92.

15. Halicioglu O, Sutcuoglu S, Koc F, Yildiz O, et al. Vitamin D status of exclusively breastfed 4-month-old infants supplemented during different seasons. Pediatrics. 2012; 130(4):e921-7.

16. Mutlu GY, Kusdal Y, Ozsu E, Cizmecioglu FM, Hatun S. Prevention of Vitamin D deficiency in infancy: daily 400 IU vitamin D is sufficient. Int J Pediatr Endocrinol. 2011; 2011(1):4

17. Onal H, Adal E, Alpaslan S, Ersen A, Aydin A. Is daily 400 IU of vitamin D supplementation appropriate for every country: a cross-sectional study. Eur J Nutr. 2010;49(7):395400 .

18. Østergård M, Arnberg K, Michaelsen KF, Madsen AL, et al. Vitamin D status in infants: relation to nutrition and season. Eur J Clin Nutr. 2011; 65(5):657-60.

19. Andiran N, Yordam N, Ozön A. Risk factors for vitamin $\mathrm{D}$ deficiency in breast-fed newborns and their mothers. Nutrition. 2002; 18(1):47-50.

20. Ergür AT, Berberoğlu M, Atasay B, Şıklar Z, et al. Vitamin $D$ deficiency in Turkish mothers and their neonates and in women of reproductive age. J Clin Res Pediatr Endocrinol. 2009; 1(6):266-9. 